\title{
THE ROLE OF INTEGRATED ISLAMIC COMMERCIAL AND SOCIAL FINANCE IN REDUCING INCOME INEQUALITY IN INDONESIA
}

\author{
Arif Widodo \\ Universitas Muhammadiyah Yogyakarta, Indonesia, rifdoisme@gmail.com
}

\begin{abstract}
Recent years saw the heated debates among prominent economists on the growing inequality in advanced economies, and accordingly, many solutions to this serious problem have been put forward. Among the practical-cum-workable solution is progressive taxation for wealth and income, especially the top one percent. Such a solution, however, has been implemented in Islamic perspective what so-called, zakah which is now referred to as social finance. In this paper, using the Gini coefficient data covering 34 provinces in Indonesia over a decade, we examine whether the role of social finance in tandem with commercial finance can adequately solve the problem of wealth distribution in Indonesia, one of the largest Democratic-Muslim countries in the world. Using the Generalized Method of Moments (GMM) model, the results demonstrated that Islamic commercial finance solely is proven statistically incapable of tackling inequality while the social finance (zakah) is performing very well in this matter over all specifications. Most importantly, when both are incorporated in a model, the result showed a significant reduction in income inequality implying that the integrated Islamic finance which can be implemented in both Islamic microfinance institution and Islamic banking is more capable, as opposed to when both are separated, of helping address the income inequality problem in Indonesia.
\end{abstract}

Keywords: Integrated Islamic Finance, Social Finance, Income Inequality, GMM. JEL Classification: D63; D64; Z18.

\author{
Article history: \\ Received : October 15, 2018 \\ Revised : May 02, 2019 \\ Accepted : May 16, 2019 \\ Available online : July 30, 2019 \\ https://doi.org/10.21098/jimf.v5i2.1063
}




\section{INTRODUCTION}

A rising income inequality in advanced and developing countries has been the center of contemporary debate among economists, which focuses primarily on its measurement and the proposals concerning the solution for reducing widening gap between the top 1 percent within income levels and the rest of 99 percent. As far as debate on this matter is concerned, Stiglitz's Price of Inequality (2012) and the seminal work, Capital in the Twenty First Century, by Piketty (2014) have reignited mounting concern over income and wealth inequality in the contemporary era. As Pikety (2014) suggests in the policy recommendation, the progressive taxation especially on wealth imposed globally on the super-rich is among the viable solution to tackle inequality. Likewise, Atkinson (2015a \& 2015b) argues the similar point though puts different emphasis on taxation, suggesting that the high rate of taxation should be implemented on the basis of income earned by individuals and of inheritance and gifts received during personal's lifetime. Relying on the abovementioned proposal on how to effectively address the issue of yawning gap in income and wealth, we believe it is worth noting that, from the mainstream view, taxation is among the realistic policy to be adopted besides other alternatives, thereby putting primary emphasis upon the distribution of income among the riches which seems possible to be taxed and distributed accordingly in the form of social transfers. Given the special attention devoted to the issue of increasing income inequality, the alternative proposals that may be introduced from Islamic perspective are therefore crucial.

Policy proposals formulated previously by many economists are broadly similar to the concept of zakah in Islamic standpoint in a sense both tax and zakah are considered obligatory for the people to fulfill by paying certain amount of money to the authority responsible, be it governmental or private agencies and have social and economic purpose, as emphasized clearly by Al-Qardawi (1999). Despite the fact that they both differ fundamentally in several respects encompassing the very basic feature of the name which is not equally the same-since the nature of zakah is an obligation determined by Shari'a and act to worship God hence the substance is highly distinctive - , its permanence that cannot be abolished, its relation to the state, the minimum threshold, to the different objective and theoretical foundations, the role of zakah is of paramount importance to deal with the growing inequality between the rich and the poor, preventing over-concentration of wealth in the hands of few people. Therefore, the recent studies pertaining to the role played by zakah in addressing the socio-economic problems, most notably income inequality, have been growing and confirming the significant role of zakah in overcoming this problem. Among the recent studies were undertaken by Beik (2013), Beik and Tsani (2015), Ayuniyyah, Pramanik, Saad, and Ariffin (2017 \& 2018) for the case Indonesia; Johari, Ab Aziz, and Ali (2014) for the case of new convert (Muallaf) in Malaysia; Abdelbaki (2013) for the case of Bahrain.

The earlier works have indeed made a huge contribution to the works of zakah in the present time and to the formulation of coherent policy on zakah, yet there are certain aspects which can further be developed: given that most of studies on the role of zakah in reducing inequality have been conducted using primary data which relies on micro level and hence they have yet to cover the broader areas. 
Beik (2013), for instance, focuses on the area of DKI Jakarta as object of study, Ayuniyyah et al. (2017) studies the effectiveness of zakah distribution both for consumptive and productive purposes in three different regions in West Java. This implies the need for using the data that cover as many areas as possible, aiming to provide a comprehensive analysis, especially from the macro context.

Furthermore, it seems apparent that the previous works focus mainly on the social finance (zakat), thereby excluding Islamic commercial finance in the analysis. In regard with this, Ascarya (2016) has stressed the fundamental principle which has been deeply embedded in Islamic finance framework, explaining that Islamic finance cannot accept the clear distinction between social and commercial finance in the system, as applied to conventional system which appears unable to achieve three bottom lines. It is thus urgently needed to address the question of surging inequality problem by considering the integration between these two aspects in Islamic finance as this paper endeavors to do so.

That said, this study attempts to contribute to the earlier works dealing with the crucial issue of inequality in Islamic perspective by filling the gaps in the previous works. In doing so, this paper first seeks to put forward a macro point of view as an alternative to inequality analysis. Using the data of inequality measured by Gini coefficient, which are based on National Survey on Social Economy (SUSENAS), this paper covers 34 provinces in Indonesia. Accordingly, the data of zakah collection is employed in this study, enabling to delve further into the contribution of zakah payers, Muslims, towards inequality index reduction since zakah is an obligation of Muslim whose wealth has exceeded nisab, minimum ratio that is varied and determined by Shari'a ranging from 2.5 percent to 20 percent. To put this into perspective, it can be argued that zakah levied on Muslims intended to redistribute and prevent wealth concentration among the few can be regarded as-despite its superiority in the spiritual aspect, justice to the payers, and certainty compared to, tax. Also, it is worth noting in this case that zakah is imposed on assets, livestock, mineral products, professional earning, capital and, more recently, stock and bond, which is quite superior in comparison to tax.

Secondly, this paper aims to perform in-depth analysis of the effectiveness of Islamic commercial and social finance when interacted to address the inequality as compared to when both are not integrated. Since the previous works have yet to throw some light on such integration, it will be a novelty of this paper. To this end, it adopts dynamic panel model, which is considered as quantitative model, instead of deploying qualitative counterpart, owing to the need for the precision and robust results that can be obtained through this model as compared to the static one.

The rest of the paper is structured as follows. The debate on how to tackle income inequality is discussed in section two, coupled with explanation of the alternative concept of integrated Islamic finance. Section three describes the data and econometric technique used in this study, explaining the reasons why they are used to address the research question. The next section deals with the main findings of this study and discussions. The last section is conclusion and recommendation. 


\section{LITERATURE REVIEW}

\subsection{Theory: Roots and Solutions of Inequality}

Many economists who have been concerned with such a serious issue have so far given the considerable attention to the problem of rising income inequality. There has been a growing study undertaken to address the issue, which can classify into three views: In the first line of the study, there are several works which can in general be represented by Atkinson (2014; 2015a \& 2015b); Atkinson, Piketty and Saez (2011); Sen (1992 \& 1997); Piketty (2014); Piketty and Saez (2013a \& 2013b); and Stiglitz (2012). The wide range of literature attempts to repeatedly assert that the driving force of the inequality is the superiority of the super wealthy people, mainly those at the top 1 or 10 percent of income distribution, over the whole population. The important way, according to Stiglitz (2012) relying on political economy standpoint, by which those the richest people have earned such a huge income and capital, dominating approximately twenty percent of total income and third of capital is that the rent-seeking behavior. Such a perspective has been enabled by the deregulations and a great reliance on the pure market force in which the super-rich becomes politically influential in the decision-making process as well as in formulating the policy that make the one percent better off, including tax cut, monopoly licenses to the corporations, and huge subsidies for the rich. He also offers convincing explanation as to how the financial sector deregulations may certainly exacerbate the inequality condition since such a condition seems to economically benefit the rich by collecting the rents. This is confirmed by the empirical study conducted by Zalewski and Whalen (2010) from institutionalist perspective and Volscho and Kelly (2012) as well as Roberts and Kwon (2017) in liberal market economies.

Moreover, Piketty (2014) further argues on the basis of long historical database that the root of the inequality is the accumulation of wealth among the super riches, as can be described in his formula $r>g$, corresponding to the rate of return on capital which always grows faster than and exceeds economic growth. This implies the significant gap between $r-g$ is likely to widen inequality between those at the top income level who hold the considerable amount of $r$ and the rest of population. Based on the formula, the viable solution that must be taken into consideration is imposing global tax on capital, given that the capital can be clearly identified as compared to income. Other studies in this first line indicate the importance of progressive taxation on income, wages, bequests, property, as has been put forward by Atkinson (2014; 2015a \& 2015b) and Piketty and Saez (2013a). As such, the capital taxation in global scale can therefore be both complementary and alternative to the existing taxation system.

The second group of view (see inter alia Goldin and Katz, 2008; Mankiw, 2013; and Mankiw, 2015) appears to contradict the belief of first group of studies, demonstrating that the important roots of inequality are not necessarily a result of top 1 percent domination. They argue that it is seemingly normal that there may be inequality in the society due to the differences in education level and skills. As a result, it is implausible that the rent seeking by the rich, as Stiglitz (2012) tries to explain, is the primary cause of inequality and hence income dispersion between skilled and unskilled labors is considered entirely reasonable (Mankiw, 2013). As for the proposal of adopting progressive levy on global capital, Mankiw 
(2015) rather approves the progressive consumption tax on the wealthy people while at the same time criticizing the Piketty's formula $r>g$ which is regarded as normal (steady-state) condition in Solow growth model and does not necessarily involve a problem of wealth inequality. Accordingly, Piketty (2015) argues against the proposal for progressive consumption tax outlining the ambiguity of imposing tax on consumption since this entails the problem of identifying which type of consumption to be levied.

To sum up, the debates on how to effectively address inequality in current works conducted from mainstream standpoint focus primarily on the role of tax system imposed on the top level of income distribution, in spite of different argumentations on what to be levied. That said, the taxation system is crucially important in shaping the realistic policies for inequality reduction. With this particular regard, the third strand of standpoint has also the relatively similar system in a sense that it is aimed at distributing the wealth from those haves to the have-nots and preventing wealth concentration, namely zakah systemthough essentially and fundamentally different-which is proven to be effective in reducing inequality in the Muslim world.

A thoughtful discussion among Muslim scholars can be levied on which type of individual Muslim wealth. Al-Qardawi (1999) analyses such a discussion, explaining that there are several goods or wealth which according to Shari'a are zakatable: assets owned by individuals, livestock, gold and silver, agriculture, business goods, honey and animal products, mineral and other sea product, earning or wages of professionals, bonds and stocks. it is important to note that zakatability of those said wealth is determined by Sharia in the form of nisab (minimum amount or ratio that must be zakated), therefore the amount that must be zakated is also varied depending on the sort of wealth. As such, zakah can be considered as tax for Muslim, which also covers several wealth known in contemporary era as financial assets in the form of bonds and stocks. This indicates the broader scope of zakah in Islamic perspective aimed to attain social justice objective by reducing income inequality, and hence it can be argued that zakah has comprised the array of tax proposals for capital including nonfinancial asset, such as land, building, commercial inventory, and financial asset, such as dividend, bond, and stock, as emphasized by Piketty (2014); wages of professional labor as in Atkinson (2015b).

\subsection{Previous Studies}

There are numerous empirical studies conducted from Islamic perspective that examine the role of zakah in eliminating widening income gap, particularly in the country with large Muslim population. The study by Jehle (1994) might be the first that has dealt with the problem of inequality in Pakistan by using survey data and suggested accordingly the effectiveness of zakah in tackling inequality. In Indonesia, seminal work by Beik (2013) reveals compelling evidence regarding the substantial role performed by zakah for inequality alleviation in DKI Jakarta, which has subsequently been developed by Ayuniyyah et al. (2017) and Ayuniyyah et al. (2018) to investigate whether the consumptive-based and productive-based distribution of zakah in West Java are also successful in dealing with this matter. 
Despite the notable contributions made by previous works, there are gaps this study that seek to fill in, as mentioned in Introduction, which encompass the area covered and methodology employed. In addition, it seems clear that the existing works have achieved general consensus that Zakah is effective policy aimed to reduce inequality problem from Islamic standpoint as evidenced in many areas covered, including those regarded as urban and rural. However, there is another gap which seems to be a puzzle, namely the role of zakah as a proxy of Islamic social finance and financing representing commercial finance in reducing income inequality, based on the principle of integration between social and commercial element in Islamic finance. This gap has yet to be discussed and filled in several empirical works in this field; therefore, the endeavor to do so is of great interest to the enrichment of existing studies.

\subsection{Integrated Islamic Finance: The Concept}

The basic idea of integrating Islamic commercial and social finance in Indonesia (henceforth cited as Integrated Islamic finance) has been enshrined in the Islamic Banking Act No 21/2008, which states the possibility of Islamic banking to establish Baitul Mãl in order to serve its social role in the society. Given this, it seems extremely clear that there is no such a strict separation between commercial domain and social role in Islamic finance. However, there are a limited number of studies whose primary aim is to explore such integration, the study by Ascarya (2016) is among the important ones.

Ascarya (2016) discusses the practical model of integrated Islamic finance as implemented in micro-small financial institutions in Indonesia, well known as Baitul Māl wa Tamwīl (BMT). In this model, BMT could play its role as commercial institution while at the same time managing social funds collected from zakah, infaq, shadaqah and waqf. The mentioned funds can then be allocated according to Shari'a: Zakah must be distributed to eight beneficiaries in the form of either consumptive or productive programs, while the other infaq and shadaqah can be channeled for social purpose as well as waqf for real sector investment (building social facilities). As BMT may play a significant role in the community, Ascarya (2017) develops the integration model of BMT, enabling other Islamic financial institutions, particularly Islamic banks, to adopt such integrated finance model at the national level.

Figure 1 depicts the integrated model that may certainly be implemented in Islamic banks, as suggested by Ascarya (2017). Looking carefully at the scheme, we can see that it is apparent that the purpose of Islamic commercial finance is to channel the funds to the financial sector in the form of financing that is based on either profit-and-loss sharing (PLS) or other type of $a k \bar{a} d$. On the other hand, in order to serve social function, Islamic banks have to establish Baitul Māl, which enables it to receive zakah, infaq, shadaqah and waqf as well as to distribute accordingly. This implies that Islamic banks can serve as corresponding bank for zakah and waqf collection whereas Baitul Māl performs its role as Amil and Nadzir at once.

The collection of zakah, derived from determined wealth by Sharia (including infaq, and shadaqah) can be done by Islamic banks and subsequently be distributed by Baitul Māl to the mustahiq encompassing 8 asnāf in the form of productive and 
consumptive programs. Moreover, the collection of fixed waqf may be conducted by Baitul Māl and be used to build social waqf facilities or other waqf programs. By doing this, Islamic banks with Baitul Māl are envisaged to be capable of enhancing zakah and waqf collection and of accomplishing the macro objectives, more importantly equitable income distribution and inequality reduction.

Figure 1.

Integrated Islamic Finance Model

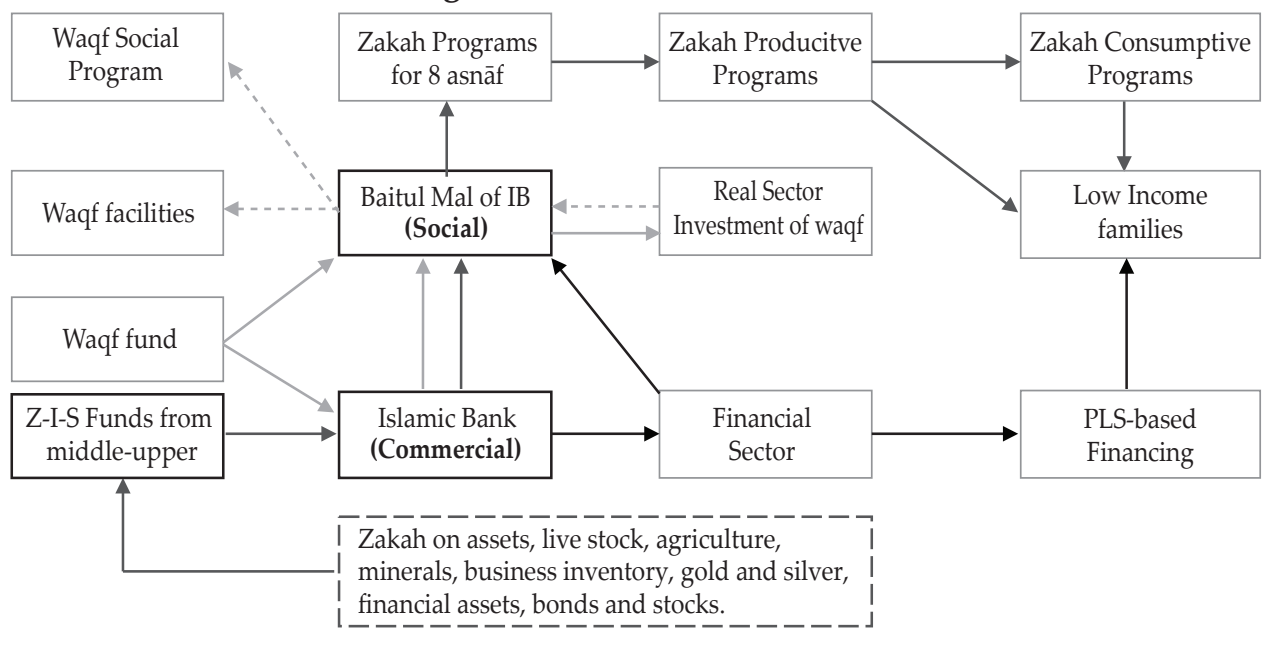

Source: Ascarya (2016)

In addition, it is worth noting that this paper opts to use zakah collection rather than distribution as many previous works did, because some Islamic scholars has considered zakah to be imposed on salaries of professionals who earns more income compared to others (Latief, 2014). He further asserts the arguments of several Islamic organizations and zakah institutions, including BAZNAS, which tend to agree with zakah on salary, derived from Ijtihād in contemporary era. The second reason why the zakah collection is employed is that it appears plausible the recent implementation of zakah on bonds and stocks in Indonesia may contribute to equitable distribution of wealth. On the other hand, profit and loss sharing embedded in Islamic financing has associated with shared prosperity (Maghrebi and Mirakhor, 2015) and promoted fairness, justice, economic growth (Ascarya and Sakti, 2008). Thus, the combination between zakah collection intended to prevent wealth accumulation and Islamic financing will probably have a greater impact on inequality alleviation.

Accordingly, this study opts for using zakah as a proxy for Islamic social finance to be integrated with commercial finance. The reasons deserve some emphasis: first, zakah has certain similarities with the tax in the way that it is an obligatory levied on the individual whose wealth and income have exceeded a certain amount to be taxed in a given period. Second, it is based on the theoretical view that zakah or tax, in mainstream perspective, is a viable solution to tackle wealth concentration and hence has a social purpose. Third, despite the significant contribution of infaq, shadaqa and waqf in Islamic social finance, those are voluntary which may 
possibly be collected from the low-middle income individual, especially for infaq and shadaqa. Instead, zakah is obliged by Sharia to be imposed on the richer people ranged in the top income distribution.

\section{DATA AND METHODOLOGY}

\subsection{Data}

To deal with the concern articulated in this study, several data that, according to the previous works, can be regarded as the proxy variables are used. The source of the data is varied, encompassing Central Bureau of Statistics, Ministry of Finance, and Bank Indonesia. The data span a decade, starting from period of 2007 to 2016 and cover 34 provinces in Indonesia. The main variable used in this study is Gini coefficient, acquired from Survei Sosial Ekonomi Nasional (National Survey on Socio Economy/SUSENAS) database, Central Bureau of Statistics. Gini coefficient (ratio) is regarded in this study as a proxy and a measurement of income inequality in the society.

That is in line with numerous studies which aim at dealing with the same issue: inequality, as can be seen in the recent works conducted by Johari et al. (2014) in Malaysian case; Beik (2013); Beik and Tsani (2015); Ayuniyyah et al. (2017); Ayuniyyah et al. (2018) in Indonesia. Most of the previous works, particularly related to prominent role played by zakah have been carried out in micro perspective by, notably, analyzing the primary data derived from zakah beneficiaries, which often consists of material aspect in the form of income before and after receiving zakah as well as spiritual aspects. To a certain extent, this study further explores the similar problem from macro perspective.

It is important also to stress that Gini coefficient has limitation. Sen and Foster (1997) explained that while Gini coefficient could meet the condition socalled Pigou-Dalton or it is also known as the principle of transfer (see Atkinson, 1970) delineating the situation when there is a transfer from those who have more income to the poorer one the measure of inequality (Gini coefficient) should adjust accordingly by a decrease in its value, the Gini appears unable to satisfy the subsequent condition, which is sensitivity. In this regard, Atkinson (1970) asserted that the Gini tends to have sensitivity to income transfers done in all level of income and yet it was doomed to fail to further explore the sensitivity in a specific income level. This remains the case for the Gini since its sensitivity rests entirely upon the number of people (population) in all income levels and therefore does not rely on the different income levels of the people (Sen and Foster, 1997). Despite the limitations of this index of inequality identified, the index is still useful and has been widely used among other measures. In addition, as the Gini is able to adjust the income transfer from the richer to the poorer people it remains capable of accomplishing the primary objective of this study. Hence, this study opts to use this Gini index as a proxy of inequality.

As for the explanatory variables, this study utilizes several government transfers, designed to examine the effectiveness of government transfers in reducing the income inequality for the bottom income, which includes the transfer to the provinces and region, grants together with social aids as planned in national and provincial budget. The available data are gathered from National Expenditure 
and Income Budget reported by Ministry of Finance, Republic of Indonesia, particularly the data for government transfer to the province and village (Dana Desa). The set of data for social aids and local-government grant is obtained from Central Bureau of Statistics, based on Provincial Expenditure and Income Budget. Atkinson (2015b) has documented the prominent role of government transfer for inequality reduction, and similarly, it will be examined in this study.

In addition to the previous explanatory variables, social finance data used are zakah collected on from annual financial report of national coordinator of zakat, National Zakat Agency (Badan Amil Zakat Nasional), which encompasses National Zakah Statistics and Indonesia Zakah Outlook. While the commercial counterpart is represented by Islamic bank financing, accessed through Islamic Banking Statistics by Financial Services Authority. The combination between both commercial and social finance for the purpose of this study is assessed and compared to government transfer, based on the concept explained in Ascarya (2017). Indeed, it is the novelty of this study compared to the previous works that mostly focus on the social finance or commercial finance only. Last but not least, the macroeconomic condition encompassing economic growth and inflation rate serves as the proxy for control variables in this study.

\subsection{Methodology and Econometric Model}

Since the data used in this study were almost unavailable, the estimation to be employed is balanced panel data regression that is pooling data from the combination of cross section data set of variables included in the model for several period of observation (time series) (Baltagi, 2008). Fortunately, by adopting this methodology, it seems likely to obtain more information from the data, degree of freedom and the variability. Moreover, as the panel regression provides the researcher to the adjustment made in the estimation and thereby exploring more information, most notably the correlation between variables in the model, that may not be acquired from the solely time series data (Gujarati, 2003). In this regard, while there is incomplete data in the observation or contains different data period, panel regression enables the researcher to carry out detailed analysis.

Similar to the time series modeling which consists of both static and dynamic model, panel data model has also such types of technique. Baltagi (2008) discusses that in the static model, there are fixed model and random model that can be employed, while the dynamic one consists of (1) Generalized Method of Moments (GMM) that is commonly used for short sample ( $T$ ) as compared to the (2) Seemingly Unrelated Regressor (SUR) that deals with the large T sample, which sometimes may be infinite.

Regardless the advantage of the panel data outlined above, static panel data contains the problem of producing bias and inconsistent estimates pertaining to the correlation with the heterogeneity effect left unobserved and this is particularly plausible in the Random effect model. Hence, to solve such a problem, the dynamic panel model, namely GMM, is used. The model was first formulated by Arellano and Bond (1991) to cope with the problem of endogenity. GMM is a model that incorporates lagged values of the endogenous variables and those considered, yet not strictly, as exogenous in both current and lagged conditions into a single 
model, serving as the instruments. This model can be differentiated into two: first difference (one-step) and system GMM model kwon as two-step model.

Given the presence of certain flaws in the one-step model of GMM, which is serial correlation in the error term since it deploys the difference of lagged variables as an instrument, and hence regarded as a weak instrument to be used, the system GMM was proposed by Arellano and Bover (1995) and Blundell and Bond (1998) to tackle such a problem in the model, and basically it was an augmentation of the former model. It is also important to note that before running GMM model, it must deal with the fundamental assumption of no second serial correlation that may certainly occur because of using lagged dependent variable to be one of independent variables. Related, to address the issue of model specification, specifically over-identification and the validity of instruments, J-statistic of Hansen is conducted as argued by Baum et al. (2002, p. 15-16) who ascertained that this test should be undertaken to examine whether or not the correlation between instruments variables with the error term exists. As such, it can be emphasized that this test is standard diagnostic to determine the suitability of the model.

Based on the aforementioned explanation, this study opts to employ this dynamic GMM model for several reasons: first, it has fewer time periods, $T$, compared to cross-sectional, $N$, as a prerequisite condition for this model to be used; second, the dependent variable of the model is dynamic which correlates to the past; third, it contains independent regressors that are not always regarded as exogenous. While the methodology adopted in this study, which is considered quantitative, differs from the recently developed methodology by Beik and Arsyianti (2015) that has been widely used, the main aim is to enrich the perspective. The model of this study consists of three models as follows:

$$
\begin{aligned}
& G_{i, t}=\alpha_{i}+G_{i, t-1}+\beta \Delta Z K C O_{i, t}+\vartheta \ln \left(\mathrm{GOVTR}_{i, t}\right)+\gamma \ln \left(H B H P R V_{i, t}\right) \\
& +\delta \ln \left(\operatorname{SOCAID}_{i, t}\right)+\varphi I N F_{t}+\tau \Delta y_{t}+\epsilon_{i, t} \\
& G_{i, t}=\alpha_{i}+G_{i, t-1}+\beta \Delta I B F I N C_{i, t}+\vartheta \ln \left(\mathrm{GOVTR}_{i, t}\right)+\gamma \ln \left(\mathrm{HBHPRV}_{i, t}\right) \\
& +\delta \ln \left(\operatorname{SOCAID}_{i, t}+\quad \varphi I N F_{t}+\tau \Delta y_{t}+\epsilon_{i, t}\right. \\
& G_{i, t}=\alpha_{i}+G_{i, t-1}+\beta\left(\Delta Z_{K C O_{i, t}} x \Delta \operatorname{IBFINC}_{i, t}\right)+\vartheta \ln \left(\mathrm{GOVTR}_{i, t}\right) \\
& +\gamma \ln \left(\text { HBHPRV }_{i, t}\right)+\quad \delta \ln \left(\operatorname{SOCAID}_{i, t}\right)+\varphi I N F_{t}+\tau \Delta y_{t}+\epsilon_{i, t}
\end{aligned}
$$

The equation (1) above is the first model, which zakah is a proxy of social finance, without interaction with the commercial counterpart. $G_{i, t}$ is Gini coefficient of $i$ province at time $t, t_{-1}$ in the right side stands for the lagged dependent variable; $\beta \Delta Z K C O_{i, t}$ is the zakah collection growth; $\vartheta \ln \left(\mathrm{GOVTR}_{i t}\right)$ stands for the central government transfer to the provinces and villages in natural logarithm; $\gamma \ln \left(H_{B H P R V_{i, t}}\right)$ denotes the amount of grant offered by provincial government for intended programs in natural logarithm; $\delta \ln \left(S O C A I D_{i, t}\right)$ is natural logarithm of social aids for several social programs conducted by provincial government; $\varphi I N F_{t}$ and $\tau \Delta y_{t}$ are inflation rate and economic growth; and $\epsilon_{i, t}$ denotes error term.

The equation (2) below depicts the presence of commercial finance excluding social finance to know whether Islamic banks can solely tackle inequality problem. 
The commercial finance is represented by Islamic banking financing growth. In addition, the third model captures the interaction between the commercial and social finance $(\triangle \mathrm{ZKCO} \times \triangle \mathrm{IBFINC})$, designed to test the performance of integrated Islamic finance in Indonesia. As noted earlier, it is expected that such integration will be more powerful in reducing inequality.

\section{RESULTS AND ANALYSIS}

\subsection{Descriptive Statistics and Correlations}

Before further discussing the main empirical evidences of this study, the explanation on the descriptive statistics of the variables incorporated in the model is provided in this section. Table 1 shows the descriptive statistics of Gini index used in this study which cover urban and rural area in Indonesia, followed by government transfer to the region and villages, grant and social aids extended by provincial government, the growth of Islamic bank financing, zakah collection growth and macroeconomic condition. According to the data average, it seems clear that the Gini coefficient in urban area is much higher than that in the rural area, with the average 0.364 and 0.308 , respectively, which is also evident when compared to the national average (0.359), indicating that there has been a disparity in income distribution in the urban area over the periods covered by this study. Moreover, when looking at the central government transfer and provincial expenditure for grant and social aids, it is evident that the grant provided by the provincial government exceeds substantially the central government transfer. Yet, that amount is slightly different form that transferred for social aids. This explains that the transfer by provincial government has been somewhat higher than central government.

Table 1.

Descriptive Statistics of Variables Used

\begin{tabular}{lcccc}
\hline \multirow{2}{*}{ Variables } & \multicolumn{4}{c}{ Statistics } \\
\cline { 2 - 5 } & Mean & Std. Deviation & Min & Max \\
\hline Gall & 0.359 & 0.039 & 0.269 & 0.459 \\
Gurban & 0.364 & 0.045 & 0.256 & 0.475 \\
Grural & 0.308 & 0.038 & 0.227 & 0.461 \\
$\ln ($ GOVTR) & 12.98 & 0.358 & 12.44 & 13.56 \\
$\ln ($ HBAHPROV) & 23.13 & 1.393 & 20.27 & 24.7 \\
$\ln ($ SOCAIDPROV) & 21.83 & 0.404 & 21.06 & 24.7 \\
INF & 5.859 & 2.686 & 2.78 & 11.06 \\
y & 5.714 & 0.613 & 4.9 & 6.5 \\
$\Delta$ IBFINC & 31.83 & 22.04 & 3.38 & 86.68 \\
$\Delta$ ZKCO & 36.69 & 22.2 & 17.75 & 84.82 \\
\hline
\end{tabular}

Notes: Gall is the cumulative gini coefficient for urban and rural area; Gurban and Grural stand for the Gini for urban and rural, respectively; $\ln$ (GOVTR) is the central government transfer to the provinces and villages, in natural logarithm; ln (HBAHPROV) denotes the natural logarithm of grant by provincial government; $\ln$ (SOCAIDPROV) represents the provincial government aids in natural logarithm; INF and y are inflation rate and economic growth, expressed in percent; $\triangle$ IBFINC stands for the growth of Islamic banking financing, while $\Delta \mathrm{ZKCO}$ depicts zakah collection growth. 
As far as the commercial and social finance indictors are concerned, it is interesting to note that the zakah collection has grown more rapidly as compared to the Islamic financing, as represented in Islamic banks financing and zakah collection growth. On average, the growth of zakah collection is 36.7 percent per annum while the financing is well under that number, 31.83 percent. Nonetheless, there has been a rapid acceleration in both Islamic commercial and social finance in Indonesia. As for macroeconomic condition, economy grows a relatively strong with 5.71 percent amid the considerable uncertainty in global economics and even the financial meltdown that erupted in 2008, while the inflation rate is, on average, slightly higher, growing 5.85 percent per year.

Table 2.

Correlations

\begin{tabular}{lrrrrrrrr}
\hline & Gall & $\Delta$ ZKCO & $\begin{array}{c}\Delta \\
\text { IBFINC }\end{array}$ & $\begin{array}{c}\ln (\mathrm{GOV} \\
\text { TR) }\end{array}$ & $\begin{array}{c}\ln (\mathrm{HBAH} \\
\text { PROV) }\end{array}$ & $\begin{array}{c}\ln (\mathrm{SOC} \\
\text { AID } \\
\text { PROV) }\end{array}$ & y & INF \\
\hline Gall & 1 & & & & & & & \\
$\Delta$ ZKCO & $-0.2115^{*}$ & 1 & & & & & & \\
$\Delta$ IBFINC & -0.1257 & 0.7372 & 1 & & & & & \\
$\ln ($ GOVTR $)$ & $0.2801^{*}$ & $-0.6679^{*}$ & $-0.5376^{*}$ & 1 & & & & \\
$\ln$ (HBAHPROV) & $0.2934^{*}$ & $-0.6166^{*}$ & $-0.3244^{*}$ & $0.9325^{*}$ & 1 & & & \\
$\ln ($ SOCAIDPROV & $-0.3664^{*}$ & $0.4530^{*}$ & $0.2197^{*}$ & $-0.5602^{*}$ & $-0.6810^{*}$ & 1 & & \\
y & -0.0062 & $0.4970^{*}$ & $0.5886^{*}$ & $-0.5618^{*}$ & $-0.4491^{*}$ & $0.1597^{*}$ & 1 & \\
INF & 0.0027 & $0.6433^{*}$ & $0.6366^{*}$ & $-0.3256^{*}$ & $-0.1517^{*}$ & -0.0272 & $0.3396^{*}$ & 1 \\
\hline
\end{tabular}

Notes: Output from pair-wise correlation; ${ }^{*}$ denotes significant level at $p<0.05$

Table 2 provides necessary information relating to the correlations among variables, and that is done using pair-wise correlation. Given the potential of this test albeit it is not formal analysis, there are at least three points to note: first, there is a strong correlation between the Gini coefficient and all government transfer in which social aids becomes the biggest ones with -0.366 followed subsequently by grant and central government transfer with 0.29 and 0.28 , respectively. Second, while it is less powerful correlation if compared to government transfer, zakah has also high correlation with gini coefficient, reaching -0.211 in comparison with financing correlation (-0.125). Third, of several government transfers and Islamic financing, three variables are negatively correlated with the gini coefficient those are zakah collection, financing growth and social aids while the other two variables have the opposite condition, correlating positively with the gini coefficient. In regards with the commercial finance, the negative correlation of Islamic financing with Gini ratio appears statistically insignificant. As for macroeconomic conditions, economic growth shows a negative correlation with the Gini, whereas the inflation rate seems to be positively related to inequality. If compared to other variables mentioned previously, the macro variables look relatively weak in the correlation with the Gini. There results, however, are preliminary and the formal results are discussed in the subsequent sections. 


\subsection{Baseline Model Results}

The main result for the baseline models of this study is provided in Table 3, yet before we proceed to the discussion as noted earlier, it is crucial to first deal with the prerequisite test that should be meet by GMM model so as to obtain the consistent results and unbiased specification. In doing so, the present study employs several instrumental variables that should be limited due to the number of cross-section in the data. Those include growth of infaq and shadaqa collection, and explanatory variable that is financing growth. The said variables are used as instruments since they may not have a direct impact on the inequality reduction. Compared with zakah, which is obligatory collected from the individual ranged in the top income distribution, infaq-shadaqa considered as charitable fund can instead be collected by those in low-income household. In addition, financing growth as an element of Islamic commercial finance seems reasonable to be included due to its purpose is not always social.

Based on the result of serial Arellano-Bond autocorrelation test, the result demonstrates that there is a first-order serial correlation and yet it is statistically insignificant for second order autocorrelation. This implies that the model can pass the test and be considered free from autocorrelation that may likely occur in the dynamic panel. Moreover, the result for over-identification restriction explains that the Hansen $J$ test does not reject the hypothesis of over-identifying restrictions, indicating the instrument used in this model is valid. Given the fact that all models ( 1 to 4 ) are able to pass both tests, system GMM coefficient can therefore be considered consistent.

As for the potential bias in the coefficients, a bias test is undertaken by making a comparison between the coefficients generated from Fixed Effect (FE), GMM (difference and System) and OLS and that the results from System GMM must be between FE and OLS coefficients. The results of bias test are divided into three parts: Zakah model (estimation 1 to 4), financing model (estimation 5 to 8) and integrated model (estimation 9 to 12). Every model has four estimations resulted from FE, Diff-GMM, Sys-GMM and OLS. The results reveal that most of System GMM's coefficients in three models are between FE and OLS, implying that the coefficients are unbiased. Even when compared with difference-GMM counterpart, system GMM is deemed the best estimator to be used in the subsequent analyses (see details in table 4).

In particular, the specification in models (1) and (2) is not noticeably different, except for the additional control, which is economic growth $y$ in the latter model. In model (1), it is apparent that zakah collection growth is statistically and significantly correlated with the gini coefficient, suggesting that a 1 percentage point increase in zakah collected from the richer people can significantly reduce the gini coefficient by 0.00037 percentage point. The similar effect is also evident in the case of social aids whose effect leads to a substantial decline in inequality by 0.0214 percentage point. The number is higher than the decrease caused by zakah. In contrast, the other two sorts of transfer, namely central government transfer and provincial government grant, does not significantly affect inequality, notwithstanding the negative coefficient of provincial government grant. The results of model (2) in which another control variable, $y$, is added to the main model, appears broadly similar to those shown in model (1). The effect of zakah and social aids is negative 
and statistically significant at 5 percent with the coefficient of -0.0004 and -0.0166 , respectively, while the other explanatory variables, as explained in the model (1), are not significant.

It is worth emphasizing that both model (1) and (2) - written in equation (1), section 3-have yet incorporated the commercial finance since the aim is to evaluate the effectiveness of zakah for combating inequality and at the same time compare it with the government transfer. The significant impact of zakah on tacking inequality obtained in this study supports previous works by Beik (2013); Beik and Tsani (2015); Ayuniyaah et al. (2017 \& 2018) in Indonesia and Johari et al. (2014) in Malaysia among muallaf, despite the fact that their works were conducted by using primary data and in micro perspective.

Table 3.

Baseline Results of Sys-GMM Model

\begin{tabular}{|c|c|c|c|c|}
\hline & -1 & -2 & -3 & -4 \\
\hline & $\begin{array}{l}\text { Gini Model } \\
\text { with Zakat }\end{array}$ & $\begin{array}{l}\text { Model with } \\
\text { Growth }\end{array}$ & $\begin{array}{l}\text { Model with IB } \\
\text { Financing }\end{array}$ & $\begin{array}{c}\text { Model + } \\
\text { Interaction }\end{array}$ \\
\hline \multirow[t]{2}{*}{ GALLt-1 } & $0.515^{* * *}$ & $0.530^{* * *}$ & $0.464^{* * *}$ & $0.486^{* * *}$ \\
\hline & $(5.97)$ & $(6.47)$ & (5.99) & (5.9) \\
\hline \multirow[t]{2}{*}{$\Delta \mathrm{ZKCOt}$} & $-0.000374^{* * *}$ & $-0.000481^{* * *}$ & & \\
\hline & $(-2.93)$ & $(-4.01)$ & & \\
\hline \multirow[t]{2}{*}{$\Delta$ ZISCOt } & & & & $-0.000203^{*}$ \\
\hline & & & & $(-1.73)$ \\
\hline \multirow[t]{2}{*}{$\ln$ (GOVTRt) } & 0.00857 & 0.0183 & 0.0187 & 0.022 \\
\hline & $(0.52)$ & (1.19) & $(0.91)$ & $(0.91)$ \\
\hline \multirow[t]{2}{*}{$\ln (\mathrm{HBAHPROVt})$} & -0.00484 & -0.00536 & -0.00233 & -0.00561 \\
\hline & $(-1.15)$ & $(-1.38)$ & $(-0.50)$ & $(-0.88)$ \\
\hline \multirow[t]{2}{*}{$\ln$ (SOCAIDPROVt) } & $-0.0214^{* * *}$ & $-0.0166^{* *}$ & $-0.0221^{* * *}$ & $-0.0193^{* *}$ \\
\hline & $(-3.27)$ & $(-2.63)$ & $(-3.51)$ & $(-2.68)$ \\
\hline \multirow[t]{2}{*}{ INFt } & $0.00197^{* *}$ & $0.00177^{*}$ & -0.000225 & 0.00111 \\
\hline & $(2.33)$ & -2.02 & $(-0.34)$ & (1.37) \\
\hline \multirow[t]{2}{*}{$\Delta y t$} & & $0.0111^{* * *}$ & $0.00988^{* * *}$ & $0.0109^{* * *}$ \\
\hline & & (4.66) & (4.03) & $(4.06)$ \\
\hline \multirow[t]{2}{*}{$\Delta$ IBFINCt } & & & -0.00598 & \\
\hline & & & $(-0.57)$ & \\
\hline \multirow[t]{2}{*}{$\triangle \mathrm{ZKC} \times \triangle \mathrm{IBFINC}$} & & & & $-0.000314^{* *}$ \\
\hline & & & & $(-2.43)$ \\
\hline \multicolumn{5}{|l|}{$P$-values } \\
\hline $\mathrm{AR}(1)$ & 0 & 0 & 0 & 0 \\
\hline $\mathrm{AR}(2)$ & 0.12 & 0.384 & 0.107 & 0.537 \\
\hline Hansen's J-stat & 0.11 & 0.177 & 0.217 & 0.134 \\
\hline
\end{tabular}

Notes: GALL is the gini coefficient for both urban and rural area in 33 provinces covered in the data; $\triangle \mathrm{ZKCOt}$ and $\triangle \mathrm{ZISCOt}$ stand for a rate of zakah collection growth and zakah, infaq and shadaqa collection, respectively. $\ln ($ GOVTRt), $\ln (\mathrm{HBAHPROVt})$, and $\ln$ (SOCAIDPROVt) are several central government transfers to the provinces, grants and social aids set in provincial government budget; $\triangle$ IBFINCt denotes the growth in Islamic bank financing as a proxy of commercial finance while $\Delta \mathrm{ZKC} \times \Delta \mathrm{IBFINC}$ is the interaction between social and commercial finance, referred to as integrated Islamic finance defined here. The control variables from macroeconomic condition are inflation and economic growth. The financing growth and infaq-shadaqa collection is used as instrumental variables in the model due to the indirect effect arisen from the variables on inequality.

In addition, p-AR(1), p-AR(2) and p-Hansen's J test stand for the probability value of autocorrelation (1), (2) and Hansen test for over-identification, hence validity of the instruments, respectively; $t$ statistics in parentheses. ${ }^{*}$ denotes the significant level $<0.1$, ${ }^{* *} \mathrm{p}<0.05,{ }^{* * *} \mathrm{p}<0.01$. 
In other words, the role of zakah in tacking inequality and promoting in tacking inequality and promoting welfare of the beneficiaries is qualitatively and quantitatively proven, even when the study is conducted from the macro perspective. Moreover, since zakah collected from those in the middle and top income who have assets and income that exceed a certain threshold ( 2.5 percent) is defined tax by some Islamic scholars as the redefinition of zakah in contemporary era (see Latief, 2014), the result of this study is in agreement with the proposal of progressive taxation introduced by Piketty (2014) who argues that global capital taxation may certainly reduce concentration of wealth among the few, and similarly Atkinson (2015a) who brings forward the income and wage taxation.

The same result for zakah is also prevalent in specification (3) and (4), based on equation (2) and (3), respectively, along with the social aids from government. In this particular regard, Atkinson (2015b) affirms that the existence of government transfer has remarkably been successful at reducing income inequality, most notably in the European countries after World War. He documents such a condition that persisted in post-war period was caused by the emergence of welfare state in most European states and the social transfer which was relied greatly on the adoption of progressive taxation system. The key finding of this study, particularly associating with zakah and social transfer, confirms the recent proposal that is formulated by prominent economist and based on the historical sketch that outlines how to effectively cope with inequality.

Model (3) then puts a great emphasis the role of commercial finance for inequality reduction, as is clear that it seems unlikely the that financing is able to cause a marked decline in income disparity regardless its negative sign of coefficient $(-0.0059)$. However, when the commercial and social finance is integrated as in model (4), the finding demonstrates the opposite: an increase of 1 percentage point in the interaction between zakah and Islamic financing, so-called integrated Islamic finance, cause a decrease of 0.031 percent in inequality which is essentially higher than the coefficient of zakah, infaq/shadaqa ( $\triangle \mathrm{ZISCO}$ ) included also in the model (4), which is approximately -0.0002. It indicates the superiority of the integrated model over the separated model. As noted earlier by Ascarya (2017), the integrated finance model could benefit low income families and those in need by consumptive and productive programs to stimulate consumption, distribute income more equitably and at the same time through productive distribution, encourage the entrepreneurship among them. Hence, an Islamic bank that seems to be focusing on the business to gain more profit, through this model, can contribute substantially to combat income disparity. The stimulating idea of managing zakah funds for socio economic development is suggested also by Bremer (2013) in the case of Middle Eastern countries, notably Egypt despite the debate among Muslim jurists ('Ulama) regarding the possibility of zakah to be distributed in such a scheme (Mahmud and Shah, 2009).

\subsection{Robustness Checks}

In the pursuit of model consistency, it is thus necessary to undertake several sensitivity checks with different specification though the model is still based on the baseline model. All specifications provided in table 4 below are arranged 
systematically according to the equation (1) which focuses solely on zakah, equation (2) that concerns mainly the performance of Islamic financing and then the integrated model with the interaction between social and commercial as in equation (3). Accordingly, the gini index in the subsequent analysis is divided based on the measurement of inequality in rural and urban areas, intended to analyze as to whether there is a marked different compared to baseline model and to ascertain how the zakah, Islamic financing and integrated both of them can have the effect on the inequality reduction. Last but not least, the estimation models presented in table 5 have satisfied the test for instrument validity since there is no second order autocorrelation (AR2) and $J$-Hansen statistics indicates the overidentifying restrictions and hence validating the instruments, which encompass the similar variables as in baseline model, in seven specifications. This confirms the GMM coefficient to be used in the formal analysis.

Column (1) and (2) show the estimation results of the performance of zakah in addressing inequality in rural and urban area, respectively. The findings in both areas exhibit consistent coefficients as that in baseline model, indicating the role served by zakah in combating inequality. Yet, there is a different success rate of zakah in reducing inequality, as seen from the coefficient. If compared, the negative coefficient for rural area is very much lower than that for urban counterpart: -0.00038 and -0.00063 respectively. This implies that zakah can serve more influential role in tackling this problem in urban area as an increase in zakah collection by 1 percent in that area leads to a 0.00063 percent decrease in disparity. 


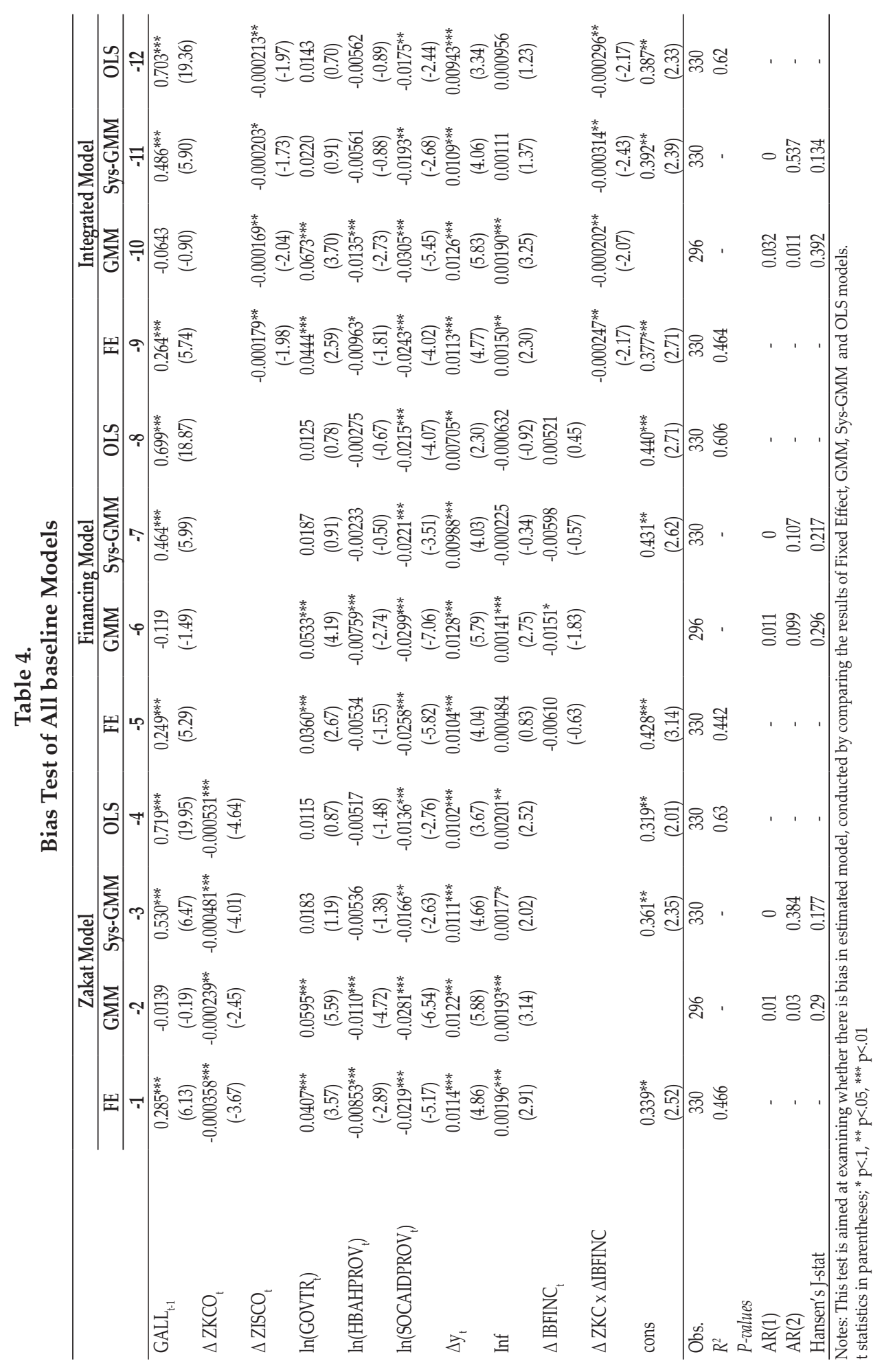


Table 5.

Robustness Checks

\begin{tabular}{|c|c|c|c|c|c|c|c|}
\hline & (1) & (2) & (3) & (4) & (5) & (6) & (7) \\
\hline & $\begin{array}{c}\text { Gini ratio } \\
\text { Rural } \\
\text { Zakah }\end{array}$ & $\begin{array}{c}\text { Gini ratio } \\
\text { Urban } \\
\text { Zakah }\end{array}$ & $\begin{array}{l}\text { Gini ratio } \\
\text { Rural } \\
\text { IB } \\
\text { Financing }\end{array}$ & $\begin{array}{l}\text { Gini ratio } \\
\text { Urban } \\
\text { IB } \\
\text { Financing }\end{array}$ & $\begin{array}{c}\text { Gini ratio } \\
\text { Rural in } \\
\text { Integrated } \\
\text { model }\end{array}$ & $\begin{array}{c}\text { Gini ratio } \\
\text { Urban in } \\
\text { Integrated } \\
\text { model }\end{array}$ & $\begin{array}{l}\text { Gini ratio } \\
\text { ALL in } \\
\text { Integrated } \\
\text { model }\end{array}$ \\
\hline Grural $_{t-1}$ & $\begin{array}{c}0.496^{* * *} \\
(6.46)\end{array}$ & & $\begin{array}{c}0.427^{* * *} \\
(6.17)\end{array}$ & & $\begin{array}{c}0.486^{* * *} \\
(6.86)\end{array}$ & & \\
\hline Gurban $_{t-1}$ & & $\begin{array}{c}0.512^{* * *} \\
(6.56)\end{array}$ & & $\begin{array}{c}0.404^{* * *} \\
(5.13)\end{array}$ & & $\begin{array}{c}0.448^{* * *} \\
(5.31)\end{array}$ & \\
\hline GALL $_{t-1}$ & & & & & & & $\begin{array}{c}0.473^{* * *} \\
(5.75)\end{array}$ \\
\hline$\Delta \mathrm{ZKCO}_{t}$ & $\begin{array}{c}-0.000388^{* * *} \\
(-2.94)\end{array}$ & $\begin{array}{c}-0.000630^{* * *} \\
(-3.63)\end{array}$ & & & & & \\
\hline$\Delta \mathrm{ZKCO} x \Delta \mathrm{IBFINC}$ & & & & & $\begin{array}{c}-0.00115^{* * *} \\
(-3.46)\end{array}$ & $\begin{array}{c}-0.00153^{* * *} \\
(-3.50)\end{array}$ & $\begin{array}{c}-0.00109^{* * *} \\
(-3.15)\end{array}$ \\
\hline $\ln \left(\right.$ GOVTR $\left._{t}\right)$ & $\begin{array}{c}0.0329^{* *} \\
(2.12)\end{array}$ & $\begin{array}{c}0.0114 \\
(0.53)\end{array}$ & $\begin{array}{c}0.0467^{* *} \\
(2.63)\end{array}$ & $\begin{array}{c}-0.000960 \\
(-0.04)\end{array}$ & $\begin{array}{c}0.0440^{* * *} \\
(3.01)\end{array}$ & $\begin{array}{l}0.0315 \\
(1.18)\end{array}$ & $\begin{array}{c}0.0338^{*} \\
(2.03)\end{array}$ \\
\hline $\ln \left(\mathrm{HBAHPROV}_{t}\right)$ & $\begin{array}{c}-0.00736^{* *} \\
(-2.10)\end{array}$ & $\begin{array}{c}0.00109 \\
(0.21)\end{array}$ & $\begin{array}{c}-0.00903^{* *} \\
(-2.23)\end{array}$ & $\begin{array}{c}0.00815 \\
(1.50)\end{array}$ & $\begin{array}{c}-0.0124^{* * *} \\
(-3.33)\end{array}$ & $\begin{array}{c}-0.00629 \\
(-0.93)\end{array}$ & $\begin{array}{c}-0.0100^{* *} \\
(-2.32)\end{array}$ \\
\hline $\ln \left(\mathrm{SOCAIDPROV}_{t}\right)$ & $\begin{array}{c}-0.00645 \\
(-1.38)\end{array}$ & $\begin{array}{c}-0.0149^{* *} \\
(-2.06)\end{array}$ & $\begin{array}{c}-0.0164^{* * *} \\
(-2.84)\end{array}$ & $\begin{array}{c}-0.0204^{* * *} \\
(-3.30)\end{array}$ & $\begin{array}{c}-0.0151^{* * *} \\
(-3.73)\end{array}$ & $\begin{array}{c}-0.0304^{* * *} \\
(-4.59)\end{array}$ & $\begin{array}{c}-0.0268^{* * *} \\
(-4.34)\end{array}$ \\
\hline$\Delta \mathrm{y}_{t}$ & $\begin{array}{c}0.0105^{* * *} \\
(3.41)\end{array}$ & $\begin{array}{c}0.0138^{* * *} \\
(4.64)\end{array}$ & $\begin{array}{c}0.00562^{*} \\
(1.79)\end{array}$ & $\begin{array}{c}0.0140^{* * *} \\
(3.24)\end{array}$ & $\begin{array}{c}0.0126^{* * *} \\
(3.38)\end{array}$ & $\begin{array}{c}0.0158^{* * *} \\
(3.69)\end{array}$ & $\begin{array}{c}0.0125^{* * *} \\
(4.34)\end{array}$ \\
\hline $\mathrm{INF}_{t}$ & $\begin{array}{c}0.00189^{*} \\
(1.87)\end{array}$ & $\begin{array}{c}0.00248^{*} \\
(2.02)\end{array}$ & $\begin{array}{c}-0.000694 \\
(-0.90)\end{array}$ & $\begin{array}{c}0.000857 \\
(0.83)\end{array}$ & $\begin{array}{c}0.00147 \\
(1.69)\end{array}$ & $\begin{array}{c}0.00149 \\
(1.38)\end{array}$ & $\begin{array}{c}0.000993 \\
(1.24)\end{array}$ \\
\hline$\Delta$ IBFINC $_{t}$ & & & $\begin{array}{c}0.0209^{*} \\
(1.95) \\
\end{array}$ & $\begin{array}{c}-0.0294 \\
(-1.67) \\
\end{array}$ & & & \\
\hline P-values & & & & & & & \\
\hline $\begin{array}{l}\operatorname{AR}(1) \\
\operatorname{AR}(2)\end{array}$ & $\begin{array}{c}0 \\
0.679\end{array}$ & $\begin{array}{c}0 \\
0.802\end{array}$ & $\begin{array}{c}0 \\
0.908\end{array}$ & $\begin{array}{c}0 \\
0.842\end{array}$ & $\begin{array}{c}0 \\
0.292\end{array}$ & $\begin{array}{c}0 \\
0.972\end{array}$ & $\begin{array}{c}0 \\
0.594\end{array}$ \\
\hline Hansen's J-stat & 0.15 & 0.205 & 0.179 & 0.163 & 0.172 & 0.113 & 0.143 \\
\hline
\end{tabular}

Notes: $t$ statistics given in parentheses and $p$ indicates the prob. value of AR (1), AR (2) and Hansen's J test for the fulfilment over-identifying restrictions and instruments used.

${ }^{*} p<0.1{ }^{* *} p<0.05,{ }^{* * *} p<0.01$

This finding confirms the recent study conducted in Indonesia by Ayuniyyah et al. (2018) who took micro perspective using primary data from zakah beneficiary's three areas in West Java including Bogor, Sukabumi and Depok. They found a greater reduction index of inequality, as represented by Gini coefficient, in urban area by 0.019 compared to the rural one with 0.011 . As such, based on both qualitative and quantitative analysis, the findings suggest that zakah is now becoming increasingly crucial to be the tools for addressing inequality, especially in urban area. Similarly, Beik (2013) who has extensively studied the substantial role played by zakah in metropolitan city, that was Jakarta, argues in the result of his seminal work that the inequality could be reduced by nearly 0.60 percentage point. As for the government transfer impact, the results are mixed. Social aids, $\ln ($ SOCAIDPROV) seems to have a consistent result as compared to 
the baseline, showing a negative coefficient yet it is significant only in urban area, while the provincial government grant, $\ln (\mathrm{HBAHPROV})$, is effective in addressing inequality in rural area. When it comes to central government transfer $\ln ($ GOVTR), the effect is striking as it increases statistically the inequality index in the rural area compared urban in which there is no such an effect. However, it seems plausible since all specifications in the baseline indicate the similar relation, which is positive although not statistically significant.

As for the specification that mainly focuses on the extent to which the growth of Islamic banking financing, $\triangle$ IBFINC impacts inequality in rural area as presented in column (3) and (4) for urban. What is striking from the findings of this model is the different impact of Islamic financing. It is apparent that in the rural area, $\Delta$ IBFINC is positively associated with and statistically significant in rising inequality in the rural area by 0.0209 percentage point, whereas the opposite result emerges in urban area with -0.0294 though it is not statistically significant. Such a finding points towards the limitations of commercial finance in terms of dealing with growing inequality, meaning that when it focuses only on commercial finance, it may never achieve the social justice and maqashid syari'ah in general. Moreover, the social aids perform its prominent role for disparity reduction in both rural and urban area, while the grant and central government transfer remain highly consistent with the results in previous specifications.

Given the limitations of Islamic commercial finance, notably to properly address the issue of income inequality as evidenced in this study, it is therefore urgent to seek to incorporate the commercial and social finance in the model by looking at the interaction model in column (5) and (6) for rural and urban, respectively. The finding shows that the integrated Islamic finance, $\Delta \mathrm{ZKCO} \times \Delta$ IBFINC, is able to reduce income inequality in both rural and urban area as can be seen from the negative coefficients in the models which are significantly correlated with Gini index. The coefficient for urban are, however, is somewhat higher than that of rural and national (ALL) model in estimate model (7). It means that 1 percent rise in $\triangle \mathrm{ZKCO} \times \Delta$ IBFINC results in 0.00153 percentage point decrease inequality in urban area, compared to 0.00115-point decline in rural counterparts and 0.109 percentage point in national (ALL) level. It is also crucially important to compare the coefficient of zakah when separated and that of integrated Islamic social (zakah) and commercial (financing) which sound quite clear that there is marked increase of the coefficient when zakah is integrated with financing. Zakah coefficients in separated model in column (1) and (2) are -0.00038 percentage point and -0.00063 percentage point for rural and urban, and these numbers, when integrated in the interaction model, have reached -0.00115 and -0.00153 , nearly triple that in separated model. At the same time, Islamic financing (commercial) that is positively correlated in rural area before interacting with social finance is now becoming negative and statistically significant in both areas as well as at national (ALL) level after the integration.

The all government transfer, including central government transfer, provincial government grant and social aids in integrated model has similar coefficient as in other separated models, in other words they remain consistent, and thus to the same extent robust. Social aids, in particular, is by far the most important transfer made by the provincial government to adequately redistribute the wealth from the richest since this variable appears negatively and statistically significant in all 
specification regardless the estimation model used. Its coefficient ranges between -0.015 and -0.30 for rural and urban area, indicating that it performs more significant role in urban area.

As far as macroeconomic controls are concerned, it is evident that economic growth has significantly positive effect in all models presented in table 4 above, as opposed to the inflation rate that seems significant in the model (1) and (2). The positive relation between economic growth and inequality deserves explanation. Such a relation was emphasized long ago by Kuznets (1955) who argued that the nation that had been in a gradual transition from agricultural to industrial onein the mid of development process - saw the positive relation between economic growth and inequality. The Kuznets's thesis has been empirically examined by Yang and Greaney (2016) in Asia Pacific countries as well as Nielsen and Alderson (1995) from sociological standpoint. It is reasonable that Indonesia is likely to experience the similar thing.

\subsection{Analysis}

This present study demonstrates compelling justification of the prominent role by zakah in reducing income inequality, portrayed in Gini coefficient. It can be justified that when the amount of zakah collected from the top one or ten percent of income distribution rises, there seems to be followed by a marked decrease in the Gini index, indicating that the condition is more equal. In this particular regard, the finding of the present study may not differ from the earlier studies in research interest among others Beik (2013); Beik and Tsani (2015); Ayuniyaah et al. (2017 \& 2018), however it does cover almost all provinces around Indonesia. It seems highly likely that the clear consensus on effectiveness of zakah in alleviating income inequality has been reached regardless of the different time span used in those studies, which has been based on the micro and macro perspective. These findings derived from Indonesian context and from Islamic perspective are essentially in agreement with the internationally-held view on taxation proposed recently by Piketty (2014) and Atkinson (2015b), to name the few, who extensively discuss the possibility of taxing the wealth owned by the super-rich, the top one percent to reduce inequality considerably.

The second point that needs to be noted is the empirical result of Islamic commercial finance presented in the present study, which suggest that financing is to such an extent inadequate to tackle the inequality problem in Indonesia. This further underlines that the triple bottom lines including outreach, sustainability and welfare impact, as pointed out by Ascarya (2017) may not certainly be achieved by solely relying on financing. Given that empirical evidence, the present study tries to investigate in detail the principle of integration embodied in Islamic finance has an ability to help reduce income gap in the society.

The capability of integrated Islamic finance that combines commercial and social aspect into a single framework to combat inequality is proven in the present findings. The key point is that the decrease of inequality because of this integrated system is more significant in urban area compared to the rural counterpart. The findings point towards the success of integrated Islamic finance to be implemented in urban area. Considering the fact that the operation of Islamic banks is mostly in urban areas, it is reasonable that Integrated Islamic finance in this study is 
more effective in such areas. Therefore, this will be interesting to ask as to how the system works in the case of microfinance institution operated in rural areas, examining whether the microfinance credit and zakah can serve a greater role in tackling this issue. This gap is left unexploited for the future research.

Last but not least, the contribution of government transfers, mainly social aids and grant, provided by provincial government is somewhat higher - as seen from coefficient-in reducing inequality compared with the zakah as well as Islamic commercial and social interaction. The reason why such a condition takes place is because government assistance can reach more areas while zakah institution and Islamic banks still have a limited access and branch. In addition, it is worth noting that the grant is effective only in reducing inequality in rural area, partly due to the fact the there are several government grants in the form of empowerment programs which has been provided for rural areas where many economic potentials have yet to be unlocked.

\section{CONCLUSION AND RECOMMENDATION}

\subsection{Conclusion}

In this paper, the role that may be performed by zakah is empirically examined as a proxy for Islamic social finance and Islamic banking financing as a representation of Islamic commercial finance in tackling inequality in Indonesia. Compared to previous works in this field that mostly address the issue from micro perspective by using primary data, the paper rather tries to deal with it in macro perspective deploying quantitative methodology and inequality data for 34 provinces in Indonesia.

Based on the three baseline models, the results reveal the superiority of social finance (zakah) in reducing income inequality over Islamic banking financing, which accounts for the fact that zakah seems capable of solely determining inequality reduction as opposed to Islamic financing. However, when both are integrated in a single model, the findings show the opposite, suggesting that inequality can be reduced by integrating both instruments. Moreover, we also conduct the robustness test by dividing the inequality in two different areas, namely rural and urban area.

The results derived from robustness checks appear to be consistent and robust over all specifications as is clear that zakah leads to decrease in inequality in both rural and urban areas whereas Islamic financing seems to have the opposite impact on inequality particularly in rural area. In the integrated model where both are integrated, the findings demonstrate that there is a significant increase of integrated Islamic finance to reduce inequality as compared to the separated model and this is evident in both rural and urban areas. Other results point out the significant role of government transfer, especially social aids, for inequality reduction. Finally, the paper arrives at the conclusion that the integrated of Islamic commercial and social finance in tandem with social aids from the government does play more substantial role in combating income inequality in Indonesia. 


\subsection{Recommendation}

As for the recommendation, since the integration between both commercial and social instrument indeed can significantly reduce inequality, it is highly crucial for the several institutions encompassing regulatory authority, in this case is Bank Indonesia, and BAZNAS to enact the regulation and pursue collaborative endeavor between both institutions which make collaboration between Islamic banks that does not have baitual maal yet and zakah institution possible or even better to encourage them to establish baitul maal as mandated in Islamic banking Act No 212008.

Based on the findings of the present study, it seems clear that the social responsibility of Islamic banks can possibly be fulfilled not only by undertaking corporate social responsibility (CSR) as has long been practiced but also by collecting and distributing zakah, infaq/shadaqa, and waqf. Therefore, it is recommended for practitioner to optimize Baitul Māl through distributing its social finance in the form of benevolent lending ( ardh al-hasan) as a productive program that may be disbursed by Islamic bank.

The present study has indeed the limitations, one of which is that the role of Islamic microfinance institutions, particularly in tackling social problem in rural area, was not discussed. Such institutions have undertaken the integrated Islamic finance including cash-waqf collection that is likely to be effective in reducing poverty and inequality. Pedagogically, such limitations could be a direction for future research.

\section{REFERENCES}

Abdelbaki, H. H. (2013). The Impact of Zakat on Poverty and Income Inequality in Bahrain. Review of Integrative Business \& Economics, 2(1), 133-54.

Al-Qardawi, Yusuf. (1999). Figh az-Zakat. London: Dar Al Taqwa.

Arellano, M., and Bond, S. (1991). Some Tests of Specification for Panel Data: Monte Carlo Evidence and an Application to Employment Equations. The Review of Economic Studies, 58(2), 277-97.

Arellano, M., and Bover, O. (1995). Another Look at the Instrumental Variable Estimation of Error Components Models. Journal of Econometrics, 68(1), 29-51.

Ascarya and Sakti, A. (2008). Comparing Monetary Policy Instruments Under

Dual Financial System: Interest System Vs Profit-and-Loss Sharing System. Journal of Islamic and Economics, 2(1), 7-33.

Ascarya. (2016). Integration of Islamic Commercial and Social Finance in MicroSmall Scale. Presented at International Seminar and $2^{\text {nd }}$ JIMF Call for Papers, Surabaya, October 27-28.

Ascarya. (2017). Implementing Integrated Islamic Commercial and Social Finance in Islamic Financial Institutions. Presented at Stadium General on Islamic Finance, organised by Department of Economics, Universitas Muhammadiyah Yogyakarta, December, 5.

Atkinson, A. B. (1970). On the Measurement of Inequality. Journal of Economic Theory, 2, 244-63.

Atkinson, A. B. (2014). After Piketty? The British Journal of Sociology, 65(4), 619-38.

Atkinson, A. B. (2015a). Can We Reduce Income Inequality in OECD Countries? Empirica, 42, 211-23. 
Atkinson, A. B. (2015b). Inequality: What Can Be Done? Cambridge, Massachusetts: Harvard University Press.

Atkinson, A. B., Piketty, T., and Saez, E. (2011). Top Incomes in the Long Run of History. Journal of Economic Literature, 49(1), 3-71.

Ayuniyyah , Q., Pramanik, A. H., Saad, N. M., and Ariffin, M. I. (2018). Zakat for Poverty Alleviation and Income Inequality Reduction: West Java, Indonesia. Journal of Islamic Monetary Economics and Finance, 4(1), 85-100.

Ayuniyyah, Q., Pramanik, A. H., Saad, N. M., and Ariffin, M. I. (2017). The Comparison between Consumption and Production-based Zakat Distribution Programs for Poverty Alleviation and Income Inequality. International Journal of Zakat, 2(2), 11-28.

Baltagi, B. (2008). Econometric Analysis of Panel Data. John Wiley and Sons.

Baum, C. F, Schaffer, M. E, and Stillman, S. (2002). Instrumental Variables and GMM: Estimation and Testing. Working Paper 545. Boston College Economics.

Beik, I. S. (2013). Economic Role of Zakat in Reducing Poverty and Income Inequality: A Case Study in the Province of DKI Jakarta, Indonesia. LAP Lambert Academic Publishing.

Beik, I. S., and Arsyianti, L.D. (2015). Construction of CIBEST Model as Measurement of Poverty and Welfare Indices from Islamic Perspective. Al-Iqtishad: Journal of Islamic Economics, 7(1), 87-104.

Beik, I. S., and Arsyianti, L.D. (2016). Measuring Zakat Impact on Poverty and Welfare Using CIBEST Model. Journal of Islamic Monetary Economics and Finance, 1(2), 141-60.

Beik, I. S., and Tsani, T. (2015). Role of Zakat Distribution in Reducing Poverty and Income Inequality in Indonesia. In M. M Muh Yusop and N. Abdullah (eds.), Zakat and Poverty Alleviation. Kuala Lumpur: IIUM Press, pp. 198-317.

Blundell, R., and Bond, S. (1998). Initial Condition and Moment Restrictions in Dynamic Panel Data Model. Journal of Econometrics, 87(1), 115-43.

Bremer, Jennifer. (2013). Zakat and Economic Justice: Emerging International Models and their Relevance for Egypt. Paper for Third Annual Conference on Arab Philanthropy and Civic Engagement, Tunis, Tunisia, June 4-6.

Goldin, C and Katz, L. F. (2008). The Race Between Education and Technology. Massachusetts: Harvard University Press.

Gujarati, Damodar N. (2003). Basic Econometrics. Fourth Edition. New York: McGraw Hill.

Jehle, Geoffrey A. (1994). Zakat and Inequality: Some Evidence from Pakistan. Review of Income and Wealth, 40(2), 205-16.

Jerzmanowski, M and Nabar, M. (2011). Financial Development and Wage Inequality: Theory and Evidence. Economic Inquiry, 51, 211-34.

Johari, F., Ab Aziz, M. R., and Ali, A. F. M. (2014). The Role of Zakat in Reducing Poverty and Income Inequality among New Convert (Muallaf) in Selangor, Malaysia. Research in Islamic Studies, 1(3), 43-56.

Kuznets, Simon. (1955). Economic Growth and Income Inequality. American Economic Review, 45(1), 1-28.

Latief, Hilman. (2014). Contesting Almsgiving in Post-New Order Indonesia. The American Journal of Islamic Social Sciences, 31(1), 16-50.

Maghrebi, N and Mirakhor, A. (2015). Risk Sharing and Shared Prosperity in Islamic Finance. Islamic Economic Studies, 23(2), 85-115. 
Mahmud, M. W and Shah, S. S. (2009). The Use of Zakat Revenue in Islamic Financing: Jurisprudential Debate and Practical Feasibility. Studies in Islam and the Middle East, 6(1), 1-15.

Malik, B. A. (2016). Philanthropy in Practice: Role of Zakat in the Realization of Justice and Economic Growth. International Journal of Zakat, 1(1), 64-77.

Mankiw, N. G. (2013). Defending the One Percent. Journal of Economic Perspectives, 27(3), 21-34.

Mankiw, N. G. (2015). Yes, $r>$ g. So What? American Economic Review: Papers $\mathcal{E}$ Proceedings, 105(5), 43-47.

Nielsen, F and Alderson, A. S. (1995). Income Inequality, Development and Dualism: Results from Unbalanced Cross-Sectional Panel. American Sociological Review, 60(5), 674-701.

Piketty, T and Saez, E. (2013a). Optimal Labor Income Taxation. In A. J. Auerbach, R. Chetty, M. Feldstein and E. Saez (Eds.). Handbook of Public Economics (5). Oxford: North Holland, pp. 392-471.

Piketty, T and Saez, E. (2013b). Top Incomes and the Great Recession: Recent Evolutions and Policy Implications. IMF Economic Review, 61(3), 456-78.

Piketty, T and Saez, E. (2014). Inequality in the Long Run. Scinece, 344(6186), 83843.

Piketty, Thomas. (2014). Capital in the Twenty-First Century. Translated by Arthur Goldhammer. Cambridge, Massachusetts: Harvard University Press.

Piketty, Thomas. (2015). About Capital in the Twenty-First Century. American Economic Review: Papers \& Proceedings, 105(5), 48-53.

Roberts, A and Kwon, R. (2017). Finance, Inequality and the Varieties of Capitalism in Post-Industrial Democracies. Socio-Economic Review, 1-28, doi: 10.1093/ser/ mwx021

Sen, A and Foster, J. (1997). On Economic Inequality. Enlarged Edition. Oxford: Oxford University Press.

Sen, Amartya. (1992). Inequality Reexamined. Oxford: Oxford University Press.

Stiglitz, Joseph E. (2012). The Price of Inequality: How Today's Divided Society Endangers Our Future. New York: W.W. Norton \& Company.

Undang-Undang Republik Indonesia Nomor 21 Tahun 2008 Tentang Perbankan Syariah [Republic of Indonesia Act No. 21 Year 2008 on Islamic Banking].

Volscho, T. W and Kelly, N. J. (2012). The Rise of the Super-Rich: Power Resources, Financial Markets, and the Dynamics of the Top 1 Percent, 1949 to 2008. American Sociological Review, 77(5), 679-99.

Yang, Y and Greaney, T. M. (2016). Economic Growth and Income Inequality in the Asia-Pacific Region: A Comparative Study of China, Japan, South Korea and the United States. Journal of Asian Economics, http://dx.doi.org/10.1016/j. asieco.2016.10.008

Zalewski, D. A and Whalen, C. J. (2010). Financialization and Income Inequality: A Post Keynesian Institutionalist Analysis. Journal of Economic Issues, 44(3), 75777. 